\title{
Stratigraphy and Structure of Dhamtaur Area, District Abbottabad, Eastern Hazara, Pakistan
}

\author{
Shamim Akhtar ${ }^{*}$, Yasin Rahim ${ }^{2,3}$, Bin Hu², Hinyuen Tsang4, Khawaja Muhammad Ibrar ${ }^{3}$, \\ Muhammad Fahad Ullah', Saleh Ibrahim Bute ${ }^{4}$ \\ ${ }^{1}$ Department of Earth Sciences, University of Sargodha, Sargodha, Pakistan \\ ${ }^{2}$ Department of Resources and Environmental Engineering, Wuhan University of Science and Technology, Wuhan, China \\ ${ }^{3}$ Institute of Geology, University of Azad Jammu \& Kashmir, Muzaffarabad, Pakistan \\ ${ }^{4}$ CAS Key Laboratory of Crust-Mantle Materials and Environments, University of Science and Technology of China, Hefei, China \\ Email: *shamim.akhtar@uos.edu.pk
}

How to cite this paper: Akhtar, S., Rahim, Y., Hu, B., Tsang, H., Ibrar, K.M., Ullah, M.F. and Bute, S.I. (2019) Stratigraphy and Structure of Dhamtaur Area, District Abbottabad, Eastern Hazara, Pakistan. Open Journal of Geology, 9, 57-66.

https://doi.org/10.4236/ojg.2019.91005

Received: December 17, 2018

Accepted: January 27, 2019

Published: January 30, 2019

Copyright (C) 2019 by author(s) and Scientific Research Publishing Inc. This work is licensed under the Creative Commons Attribution International License (CC BY 4.0).

http://creativecommons.org/licenses/by/4.0/

\begin{abstract}
Pre-Cambrian to Paleocene age sedimentary rocks predominantly characterize the fold and thrust belt of eastern Hazara division. The Hazara Slate Formation is the oldest rock unit which represents the Precambrian sequence. The Permian and Triassic sequences are missing. The Jurassic sequence comprises Samana Suk Formation whereas the Cretaceous exposed is Chichali and Lumshiwal formations. The Eocene sequence consists of Nammal and Sakessar formations. The structural fabric of the area is mainly attributed to a series of northwest trending parallel to en echelon anticlines and synclines. Most of these folds are found to be asymmetric and are Northwest facing. Several thrust faults verging both to the north have been mapped that generally dissect the forelimbs of the anticlinal structures. But the following study going to be focus on surface structural features as well as subsurface projections of folds and faults. Study of such structural features has get prime importance in economic geology such as petroleum geology, mining geology and engineering geology. In our study area subsurface projection of folds and faults along the structural transects of the area suggests that these structures have formed as a result of shortening associated with ramping from a regional basal decollement. All the structures clearly demonstrate that the eastern Hazara area has been subjected to compressional deformation/stresses oriented northeast southwest. The repetition of rock units indicates, folding in the area and thrusting of Pre-Cambrian Hazara Formation over younger Paleocene Lockhart Formation, evidence of thrust fault. There are unconformable contacts between Hazara and Samana Suk, Chichali and Lumshiwal, Kawagarh and Hangu and Lockhart formations indicate fluctuation in the environment of deposition. The Bagnotar Fault, Dhamtaur syncline and Thai anticline are the major structural features identified and reported in the study area.
\end{abstract}




\section{Keywords}

Thrust Faults, Anticlines, Synclines, Compressional Deformation

\section{Introduction}

The Himalayan collision zone extends over $5000 \mathrm{~km}$ in Burma, Nepal, India and Pakistan [1]. This extensive zone manifests variable tectonic, structural and morphological features in Pakistani Himalayas (Figure 1) [2]. The Kohat Potwar province constitutes the western margin of Himalayan foreland fold and thrust belt which is marked by the Trans-Indus Range Thrust and Salt Range Thrust in the south where the Eocambrian to Pleistocene continental shelf sequence of Salt Ranges has thrusted southward to the Indo Gangatic Foredeep. The narrow approximately $30 \mathrm{~km}$ Himalayan foreland fold and thrust belt in India has broaden to more than $100 \mathrm{~km}$ along series of lobes in Pakistan. The study area is located in Lesser Himalayas, eastern Hazara division as, "This zone is bounded to the north by the Main Mantle Thrust (MMT) and to the south by Main Boundary

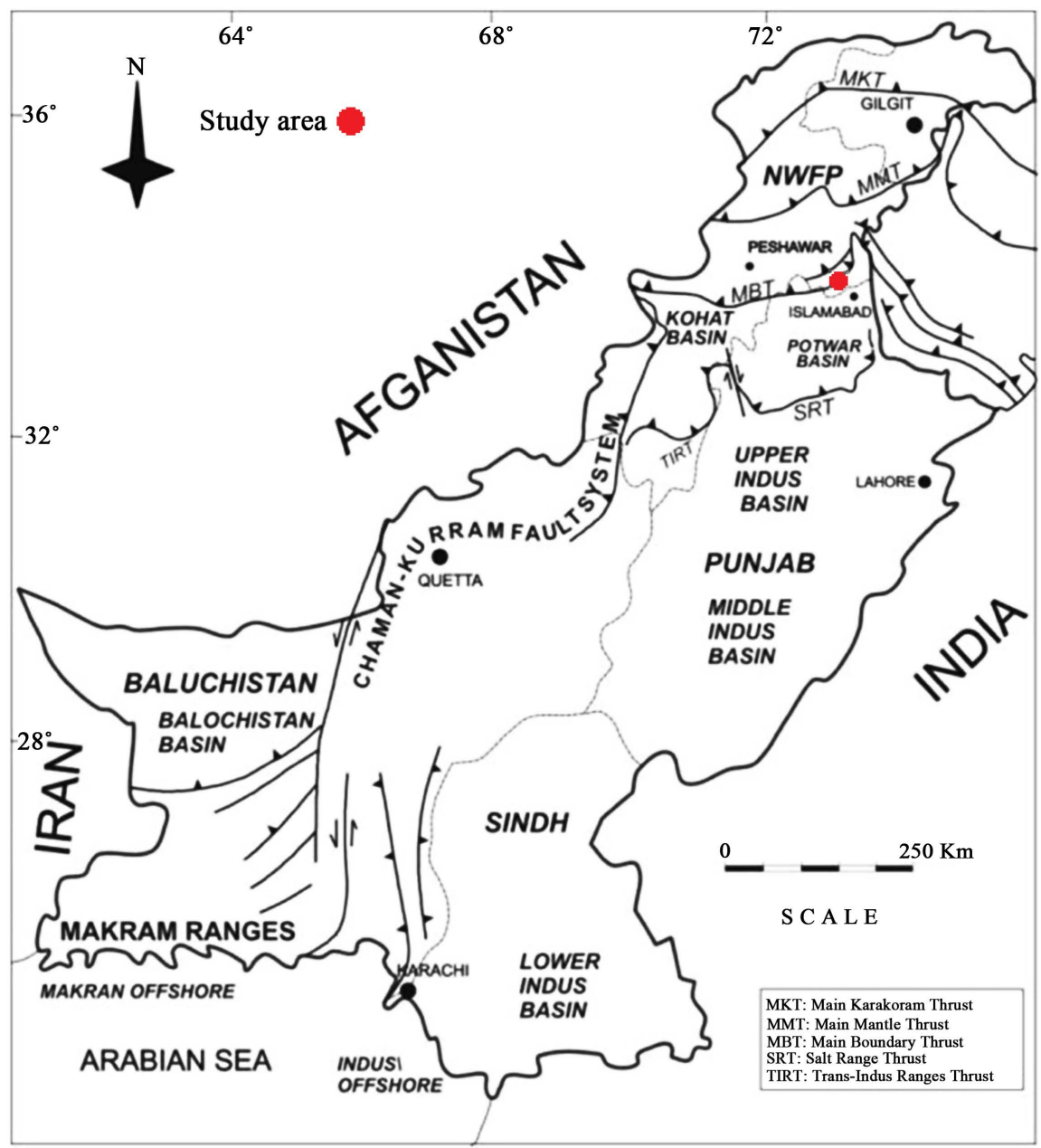

Figure 1. Tectonomorphic map of Pakistan [2]. 
Thrust (MBT)" (Figure 1). The accessibility to this area is via Murree road through Abbottabad. The area bounds in the coordinates at "Dhamtaur $\left(34^{\circ} 08^{\prime}: 73^{\circ} 16^{\prime}\right)$, Bagh-Maira $\left(34^{\circ} 08^{\prime}: 73^{\circ} 18^{\prime}\right)$, Bandi $\left(34^{\circ} 06^{\prime}: 73^{\circ} 17^{\prime}\right)$, Chanran $\left(34^{\circ} 07^{\prime}: 73^{\circ} 16^{\prime}\right)^{\prime}$. Research work on this area and its surroundings has been conducted by different workers in different field of studies mainly Paleontology, Stratigraphy, Minerology and Structural geology on regional scale [3]-[11]. This paper elaborates all available surface data used to construct cross sections to understand the structural evolution of the study area. The structures are analyzed on macroscopic scale about 0 - $500 \mathrm{~m}$ (Figure 6 and Figure 7). However, structures on small scale such as minor folds and faults in thin laminas $(0.1-0.6 \mathrm{~cm})$ were used to interpret the primary macroscopic folds and faults.

\section{Regional Geology}

About 130 m.y. ago when India started northward drift the opening of Indian Ocean in the south and squeezing of the Tethys Ocean in the north started [12]. Intra-oceanic island arcs (Kohistan-Laddakh, Noristan, Kandhar) were formed by the Intra-oceanic subduction within the Neotethys during the Cretaceous times and backarc ocean at the southern margin of Eurasia [13]. With the closure of the back-arc basins, the Kohistan Ladakh island arc under-thrusted the Eurasian plate margin along the Main Karakoram mega suture which give rise to an accreted plate tectonics similar in nature to the Andean type continental margin [14]. The youngest marine sediments deposited in the back-arc basin, between the Kohistan and Karakorum, are Early to Middle Cretaceous carbonate [15] [16]. Gravity data modeling indicates that the MMT and MKT dip northward at $35^{\circ}$ to $50^{\circ}$ [17]. Seismological data suggests that the arc underlies the Indian Crustal Plate [18] and the thickness of the Kohistan terrain based on gravity modeling data is about 8 to $10 \mathrm{~km}$ [17]. (These are the actual results of referred publications and we cannot publish their original data again). The rocks of the lesser Himalayas are thrust southward over the sub-Himalayan sequence of Neogene Siwalik molasses along the Main Boundary Thrust zone. The Main Boundary Thrust zone is comprised of a series of parallel or en echelon thrust faults dividing the NW Himalayan sequence into a deformed southern zone or foreland, and a deformed and metamorphosed northern zone or the hinterland [19]. From NE to SW, the Main Boundary Thrust is located in the Hazara Kashmir Syntaxis, northern Potwar and Kohat plateau of Pakistani Himalayas.

\section{Stratigraphy}

Exposed stratigraphic sequence in the vicinity of Dhamtaur area consists of about one and half $\mathrm{km}$ thick succession of rocks of Precambrian to Eocene age (Figure 2). The Hazara Formation is the oldest rock sequence in the area represents the Precambrian sequence consisting of Slates. The Permian and Triassic sequences are missing in this area. The Jurassic sequence comprises Samana Suk Formation which is composed of Limestone which has unconformable 


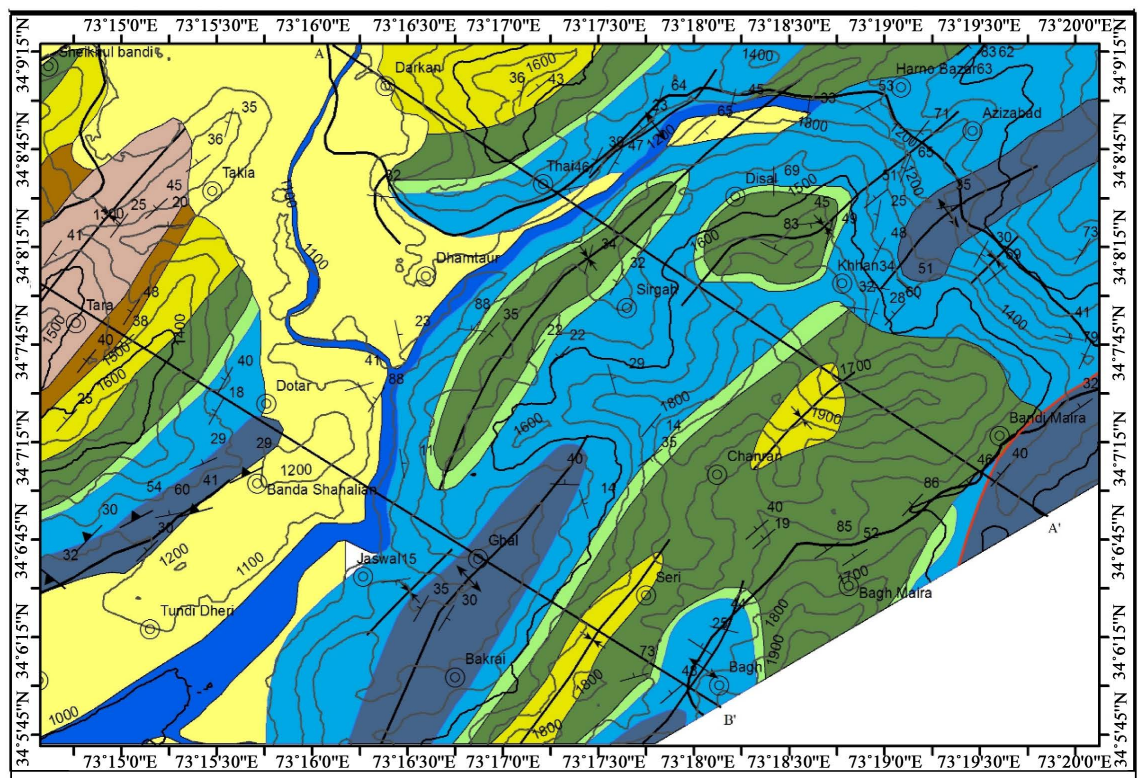

LEGEND

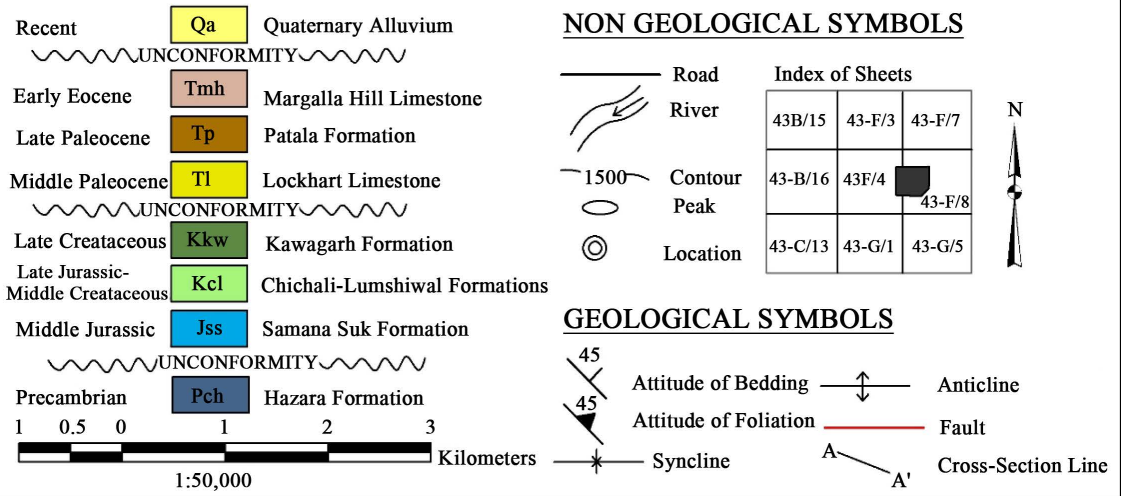

Figure 2. Geological map of the Dhamtaur area, eastern Hazara, Abbottabad District, KPK, Pakistan.

contact with Hazara Slates, whereas the Cretaceous sequences exposed are Chichali, Lumshiwal and Kawagarh formations, Chichali Formation is Shale and its lover contact is with Samana Suk Formation and Lumshiwal Formation is mainly sandstone the upper most rock unit of this sequence is Kawagarh Formation which is Limestone and its lover contact is with Lumshiwal Formation. The Paleocene sequence is composed of Hangu and Lockhart formations, Hangu is mainly comprised of sandstone and coal seams whereas the Lochkart is limestone. The Eocene sequence consists of Nammal and Sakessar formations.

\section{Main Structural Elements}

The study area is located in a fold and thrust belt and has undergone intense deformation and shortening as manifested by a number of thrust faults and various large and small scale folds (Figure 2). The overall trend of these structures is northeast-southwest, indicating northwest-southeast compressive stresses. Following is a brief description of the major structural elements of the study area. 


\section{1) Folds}

The area under study exhibits tight folding and in some areas overturning of the fold limbs has been observed. Major folds observed in the area include Thai Anticline, Ghal Anticline and Azizabad Anticline, Dhamtaur Syncline, Jaswal Syncline, Sirgah Syncline, Chanran Syncline and Disal Syncline occurs in the study area of the Dhamtaur village.

Dhamtaur Syncline is the major fold which contains Kawagarh Limestone in its core. The northern and southern flank of the mentioned anticline is undisturbed as it is built by normal sequence of Kawagarh Formation and younger sequences. The outer limbs of this fold are composed of the Pre-Cambrian Hazara Formation (shown in cross-section A-A'). The dip of the northwestern limb is $41^{\circ} \mathrm{SE}$ and the dip of southeastern limb is $25^{\circ} \mathrm{NW}$ to $45^{\circ} \mathrm{NW}$. And the strike of northwestern limb is $\mathrm{N} 36^{\circ} \mathrm{E}$ and strike of southeastern limb N $36^{\circ} \mathrm{W}$. The trend and plunge of the Dhamtaur syncline is $36.3^{\circ}-0.3^{\circ}$. The attitude of the axial plane of the Dhamtaur syncline is $\mathrm{N} 36^{\circ} \mathrm{E} / 86^{\circ} \mathrm{NW}$. The inter-limb angle of the fold is $114^{\circ}$. Therefore, on the basis of inter-limb angle the fold is classified as open (Figure 2).

The Ghal Anticline is another major fold of the study area it contains Hazara Formation in its core (shown in cross-section B-B'). The dip of the northwestern limb is $35^{\circ} \mathrm{NW}$ and the dip of southeastern limb is $30^{\circ} \mathrm{SE}$. And the strike of northwestern limb is N61E and strike of southeastern limb is N57 ${ }^{\circ}$. The trend and plunge of Ghal anticline is $59.2^{\circ}-1.3^{\circ}$. The attitude of the axial plane of Ghal anticline is $\mathrm{S} 59.6^{\circ} \mathrm{W}-87.6^{\circ} \mathrm{SE}$. The inter-limb angle of the fold is $115.3^{\circ}$. Therefore, on the basis of inter-limb angle the fold is classified as open (Figure 2).

\section{2) Faults}

The study area is a part of a major fold and thrust belt and is therefore characterized by various thrust faults. The major faults observed in the area are Bhagnotar and Nathi Gali Thrust. Bhagnotar Thrust is the major thrust. Along this thrust Precambrian rocks of Hazara Formation are thrust over Samana Suk Formation of Jurassic age. The Bhagnotar Thrust is roughly east-west oriented with undulations and bends and its dip ranges from $50^{\circ}$ to $60^{\circ}$. Nathia Gali Thrust occurs to the south of Hazara Thrust and brings Samana Suk Formation of Jurassic age in direct contact with Margala Hill Limestone of Eocene age. This thrust is also roughly east-west oriented with a dip of $60^{\circ}$ (Figure 2).

\section{Mesoscopic Structures within the Hazara Slates}

Mesoscopic structures are the structures visible at the scale of outcrop and hand specimen. Study of such structures help in strain analysis, provides information that can help in the interpretation of regional (macroscopic) structural relations and provide clues about deformation conditions and sense of movement during deformation. The deformation within the Hazara Slates of the Hazara thrust zone is represented by well developed cleavages and a variety of folds. The Ha- 
zara Slates show three sets of cleavages. The first set of cleavages S1 is bedding parallel and is much well developed as compared to the other two. The less developed S2 and S3 cleavages occur as conjugate sets (Figure 3). The deformation within the Hazara Slates appears to be the result of two phases of deformation. The first being Pre-Cambrian (primary deformation) and the second being Himalayan (secondary deformation). The bedding parallel slaty cleavage.

S1 is the result of Pre-Cambrian deformation. The S2 and S3 which are less developed as compared to the $\mathrm{S} 1$ fabric are most probably the result of Himalayan deformation. This is inferred from the fact that joints corresponding to these less pervasive cleavage sets are also present in the overlying younger carbonates. The rose diagram of cleavage data (Figure 4) is shown in (Figure 5) which is indicative of an overall NE-SW orientation of the cleavages.

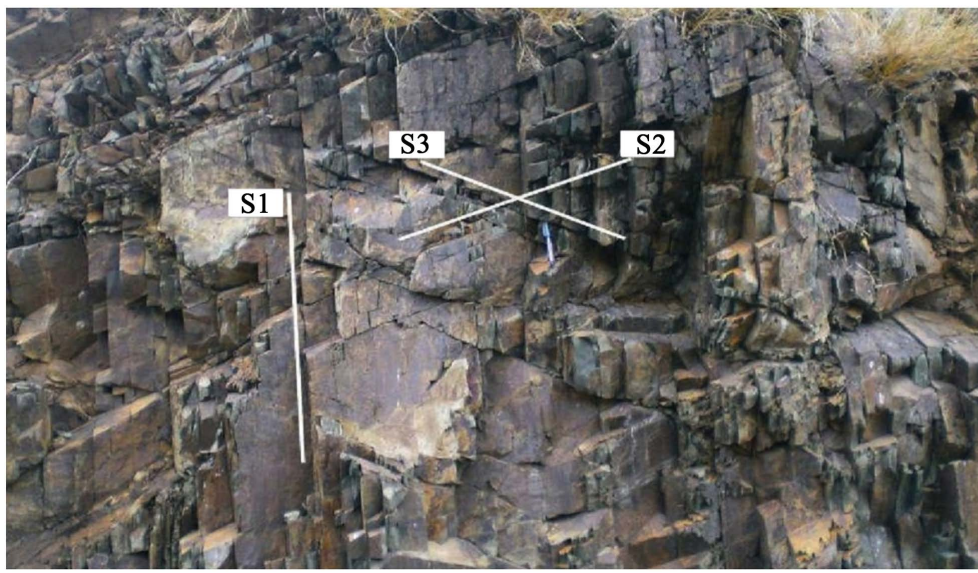

Figure 3. Hazara Slates showing three sets of cleavages (lat. $34^{\circ} 08^{\prime} \mathrm{N}$ : long. $73^{\circ} 18^{\prime} \mathrm{E}$ ). The most prominent set of cleavages is the $\mathrm{S} 1\left(330^{\circ}, 80^{\circ}\right)$. The other two sets, S2 $\left(150^{\circ}, 20^{\circ}\right)$ and $\mathrm{S} 3\left(130^{\circ}, 40^{\circ}\right)$ occur as conjugate sets and oblique to the bedding parallel cleavage set $\mathrm{S} 1$.

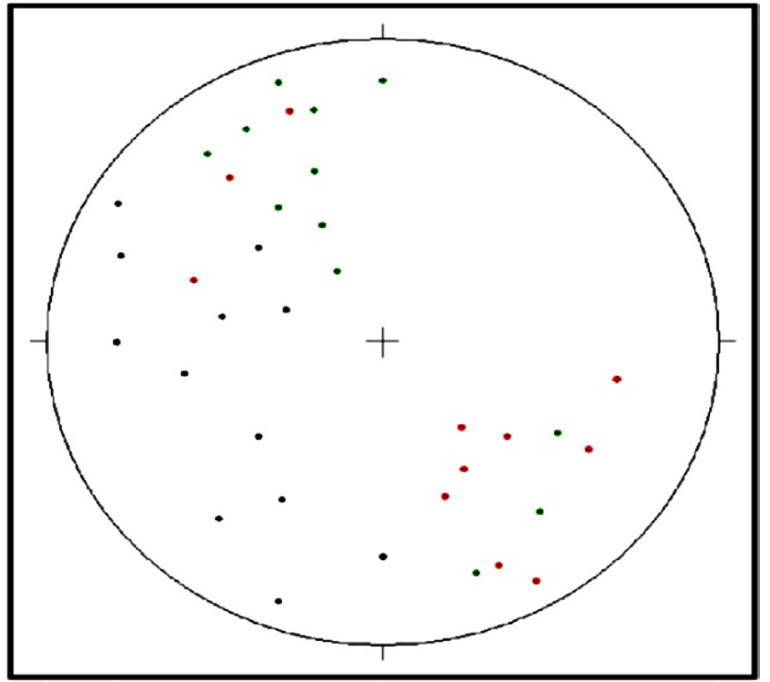

Figure 4. Orientation data of cleavage sets S1, S2 and S3 within the Hazara Slates. $\mathrm{S} 1$ the most prominent bedding planar cleavage; 'S2 cleavages; 'S3 cleavages. 


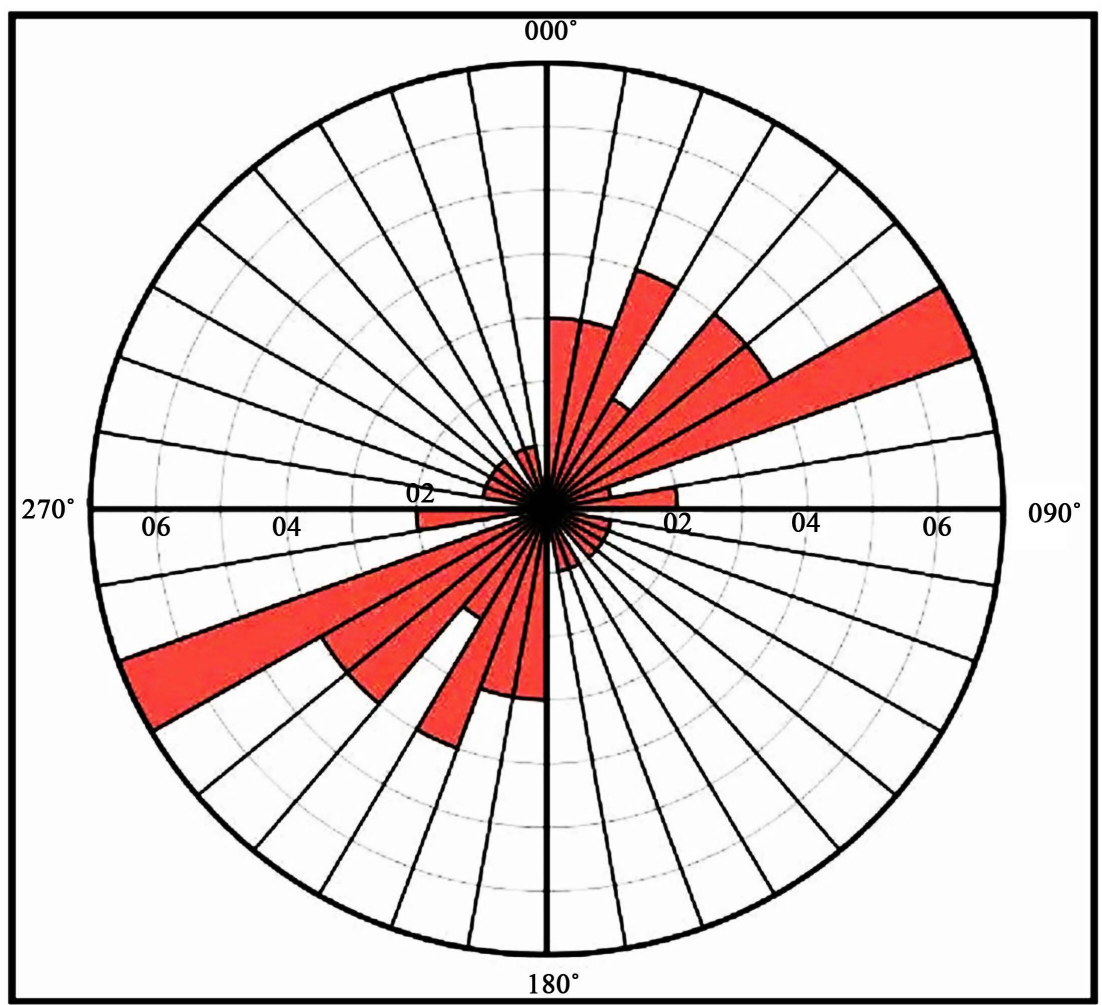

Figure 5. Rose diagram of the cleavages observed in the Hazara Slates.

\section{Structural Transects}

In order to explain the surface and subsurface geometries of the exposed structural features, two geological cross-sections, one along line $\mathrm{AA}^{\prime}$ and the other along line BB' of the map have been constructed (Figure 6 and Figure 7). The salient structural features shown in these transects are as follows.

\section{1) Transect along Line $A^{\prime}$}

The cross section line $\mathrm{AA}^{\prime}$ is parallel to the section line $\mathrm{BB}^{\prime}$ but covers the eastern part of the map. It thus shows the eastern extension of the structures depicted in the section along line AA'. The Bhagnotar Thrust was depicted in the section along line AA'. The Bhagnotar Thrust has brought the Hazara Formation on top of the Samana Suk Formation. The Dhamtaur Syncline contains Kawagarh Limestone in its core. The Thai Anticline is visible in the section $\mathrm{AA}^{\prime}$ and contains Samana Suk Formation in its core. The Chanran Syncline is present in the southeastern part of the cross section line AA' consists of Lockhart Limestone in its core.

\section{2) Transect along Line $B^{\prime}$}

The cross section line $\mathrm{BB}^{\prime}$ is parallel to the section line $\mathrm{AA}^{\prime}$ but covers the southwestern part of the map. It thus shows the southern extension of the structures depicted in the section along line BB'. The Shahallian Thrust was depicted in the section along line BB' where there were evidences crushing surfaces of thrusting present in Hazara Formation. The Ghal Anticline is visible in the section $\mathrm{BB}^{\prime}$ and contains Hazara Formation in its core. 

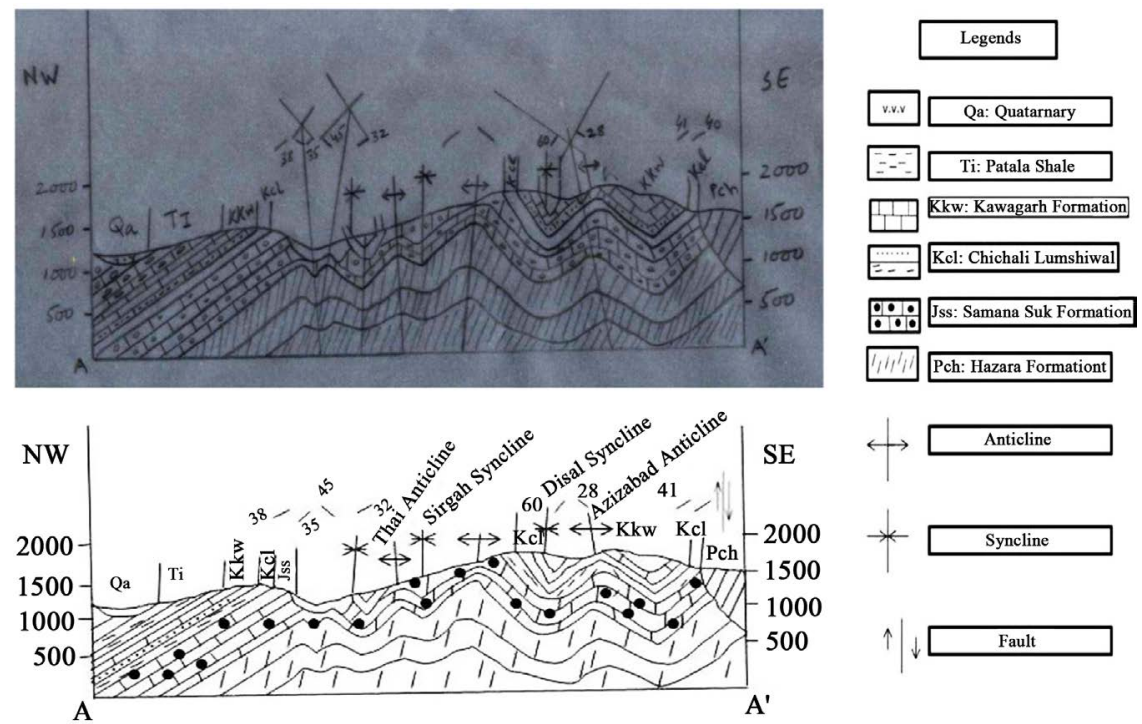

Figure 6. Geological cross section along line AA' of Figure 2.
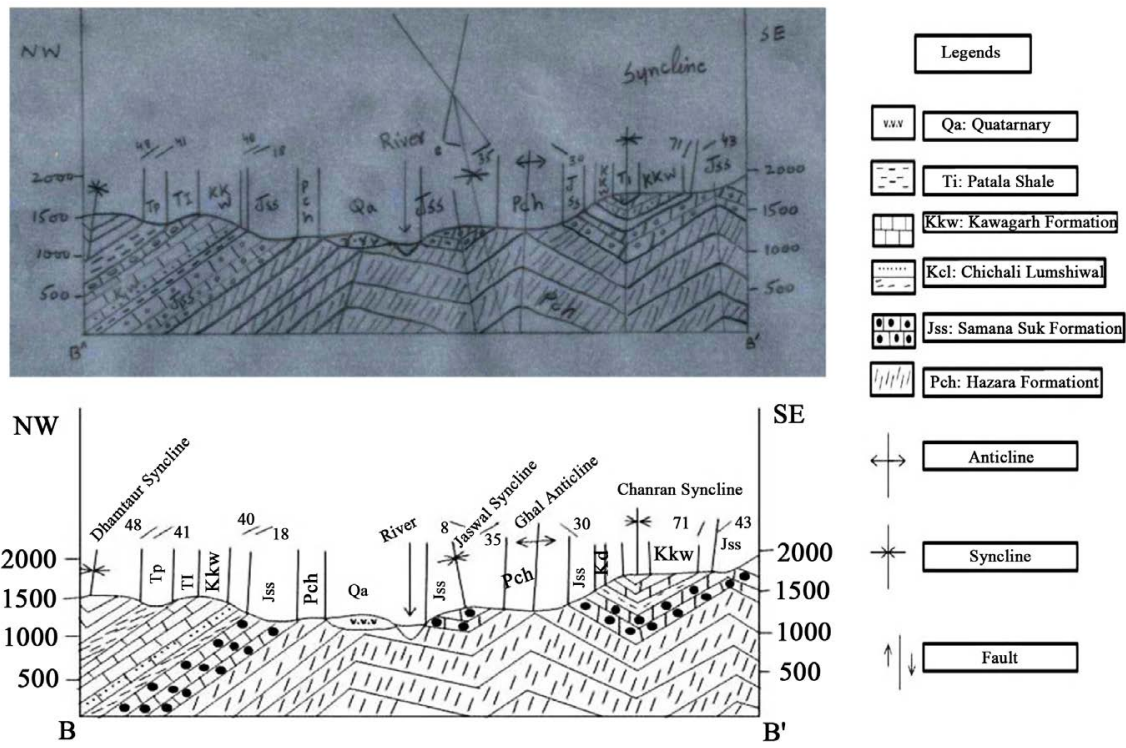

Figure 7. Geological cross section along line BB' of Figure 2.

\section{Conclusion}

The east Hazara, being very close to the north of MBT, has undergone intense deformation. In the study area this deformation is marked by southeast verging thrust faults, and northeast trending anticlines. This northeast orientation of the major structures suggests that the area has been under the influence of northwest-southeast oriented stresses. The Hazara Slates present in the northern part of the study area have recorded both Pre-Cambrian and Himalayan deformation events. The Precambrian deformation event is marked by the bedding parallel slaty cleavage (S1). The other two sets of cleavages (i.e. S2 and S3) are the result of Himalayan deformation events. This is inferred from the fact that joints corresponding to these cleavage sets have been observed in the overlying Cenozoic 
carbonates. The hinge lines of the most of folds in the study area are found to be northeast-southwest trending which also suggests that the area is subjected to northwest-southeast compressive stresses.

\section{Acknowledgements}

The author is highly grateful to CIIT Abbottabad, Pakistan and NORTHWEST Minerals (Pvt.) Ltd. for their support and constructive criticism during the completion of this work.

\section{Conflicts of Interest}

The authors declare no conflicts of interest regarding the publication of this paper.

\section{References}

[1] Gansser, A. (1981) The Geodynamics History of the Himalayas. In: Gupta, H.K. and Delany, F.M., Eds., Zagros-Hindukush Himalaya Geodynamic Evolution, V.3, 111-121.

[2] Kazmi, A.H. and Jan, M.Q. (1997) Geology and Tectonics of Pakistan. Graphic Publishers, Karachi.

[3] Latif, M.A. (1970) Micropalaeontology of the Galis Group, Hazara, West Pakistan. Geological Map. Wein Jb. Geol., B. A., Sonderb, 15, 63-66.

[4] Shah, S.M.I. (1977) Stratigraphy of Pakistan. Geol., Surv. Pakistan. Mem., 12, 138.

[5] Middlemiss, C.S. (1896) The Geology of Hazara and Black Mountains. Geol., Surv. India. Mem., 26, 302.

[6] Danilchik, W. and Shah, S.M.I. (1961) Stratigraphic Nomenclature of Formations in Trans-Indus Mountains, Mianwali District, West Pakistan: U. S. Geol., Surv. Proj. Report (IR) PK-33, 45 p.

[7] Calkins, T., Offield, W. and Ali, S.T. (1969) Geology and Mineral Resources of Southern Hazara District, West Pakistan, and Parts of Western Azad Kashmir. Prof. Report (IR) PK-43, 92 p.

[8] Fatmi, A.N. (1977) Stratigraphy of Pakistan. Geol., Surv. Pakistan, 12, 29-56.

[9] Stoliczka, F. (1866) Summary of Geological Observations during a Visit to the Provinces-Rupshu, Karnag, South Ladak, Zanskar, Suroo and Dras-of Western Tibet, 1865. Memoirs of the Geol., Surv. India. Mem., 5, 173.

[10] Ali, R., Ahsan, N., Chaudhry, M.N. and Masood, K.R. (2000) Lithofacies, Microfacies, Diagensis, Environment of Deposition and Palynology of Lumshiwal Formation at Kundla, Hazara Basin, Pakistan. Third South Asia Geological Congress, Lahore, Pakistan, $155 \mathrm{p}$.

[11] Ahsan, N., Chaudhry, M.N. and Khawaja, A.A. (2001) Tithonian to Danian Sedimentation in Hazara Basin, Northern Pakistan. Nepal Geological Congress.

[12] Johnson, G.D., Powell, C.M.A. and Veevers, J.J. (1976) Spreading History of the Eastern Indian Ocean and Greater India's Northward Flight from Antarctica and Australia. Geological Society of America Bulletin, 87, 1560-1566. https://doi.org/10.1130/0016-7606(1976)87<1560:SHOTEI >2.0.CO;2

[13] Searle, M.P. (1991) Geology and Tectonics of Karakoram Mountains. Geological Magazine, 129, 358. 
[14] Patterson, M.G. and Windley, B.F. (1985) Rb-Sr Dating of the Kohistan Arc Batholith in the Trans-Himalaya of North Pakistan and Tectonic Implications. Earth and Planetary Science Letters, 74, 54-75.

[15] Coward, M.P. (1985) A Section through the Nanga Parbat Syntaxis Indus Valley, Kohistan. Geol. Bull. Univ. Peshawar, 18, Article ID: 147152.

[16] Zeitler, P.K. (1985) Cooling History of the NW Himalaya, Pakistan. Tectonics, 4, 127-151. https://doi.org/10.1029/TC004i001p00127

[17] Malinconico, L.L. (1989) Crustal Thickness Estimates for the Western Himalaya. In: Malinconico, L.L. and Lillie, R.J., Eds., Tectonics of the Western Himalayas, Geol. Soc. Amer., Spec, city, 237-242. https://doi.org/10.1130/SPE232-p237

[18] Seeber, L. and Armbruster, J. (1979) Seissmicity of the Hazara Arc in Northern Pakistan: Decollement versus Basement Faulting. In: Farah, A. and DeJong, K.A., Eds., Geodynamics of Pakistan, Geological Survey of Pakistan, Quetta, 131-142.

[19] Pivnik, D.A. and Wells, N.A. (1996) The Transition from Tethys to the Himalayas as Recorded in North West Pakistan. Geological Society of America Bulletin, 108, 1295-1313. https://doi.org/10.1130/0016-7606(1996)108<1295:TTFTTT>2.3.CO;2 